\title{
ФОРМУВАННЯ ПРОФОРІСНТАЦІЙНОЇ КОМПЕТЕНТНОСТІ В МАЙБУТНІХ УЧИТЕЛІВ ГЕОГРАФІЇ
}

\author{
Пологовська Ю. Ю., Щабельська В. Г.
}

\section{ВСТУП}

Трансформаційні перетворення у світовій економічній системі свідчать, що конкурентоспроможність країни дедалі більше визначають не природні чи економічні чинники, а висококваліфікована робоча сила. Одним із ефективних засобів іiі формування є своєчасна та фахова профорієнтаційна робота 3 учнівською молоддю. Вона допомагає їм стати суб'єктами свого професійного самовизначення, здійснити самостійний та усвідомлений вибір майбутньої професії з урахуванням здібностей, уподобань, індивідуальних особливостей і кон'юнктури ринку праці для повноцінної реалізації в професійній діяльності.

Актуальність профорієнтаційної роботи значно підвищується у зв'язку 3 переходом школи на профільне навчання. Згідно 3 Концепцією Нової української школи, учень має зробити свій професійний вибір ще в основній школі, коли постає питання визначення профілю навчання, орієнтованого на майбутню професію.

Якість організації профорієнтаційної роботи значною мірою залежить від рівня професійної підготовки вчителів. Вони впливають на формування свідомості учнів, їх ставлення до певного шкільного предмета. Учителі проводять діагностування здібностей учнів та обирають засоби і шляхи їх розвитку. Зрозуміло, що це мають бути професіонали, які не лише володіють теорією та методикою викладання фахових дисциплін, а й орієнтуються в сучасних досягненнях науки, дидактики, здатні реалізовувати їх в освітньому середовищі, вільно орієнтуються у світі сучасних професій, уміють правильно визначати індивідуальну освітню траєкторію й програму життєдіяльності учня, можуть створити сприятливі умови для формування готовності старшокласників до професійного самовизначення, відповідно до інтересів, бажань і можливостей.

Отже, фахова підготовка майбутніх учителів географії має бути спрямована на формування в них профорієнтаційної компетентності як складника загальної професійної компетентності. Аналіз реального стану педагогічної діяльності випускників педагогічних навчальних закладів свідчить про їх недостатній рівень готовності до виконання профорієнтаційних функцій у професійній діяльності. 
Профорієнтаційна компетентність часто формується стихійно, нецілеспрямовано. Це породжує дисонанс між необхідністю проведення профорієнтаційної роботи 3 учнями на всіх етапах їх навчання та рівнем підготовки вчителя до такого виду діяльності.

\section{1. Зміст і структура профоріснтаційної компетентності майбутніх учителів географії}

Розроблення системи заходів формування профоріснтаційної компетентності в майбутніх учителів географії потребує вивчення, аналізу й узагальнення наукових напрацювань із цієї проблематики, визначення змісту і структури феномена дослідження.

Тривалий час профорієнтаційну компетентність не розглядали як окремий складник професійної компетентності, але у зв'язку 3 переходом школи на профільне навчання актуальність досліджень у цьому напрямі підвищується. Проблемі пошуку ефективних шляхів підготовки студентів до профорієнтаційної роботи в школі присвячені праці В. Андарало, М. Благініна, Г. Бондаренка, К. Жубаєва, С. Золотухіної, В. Зінченка, Х. Процко, В. Романчука, М. Свіржевського, Б. Федоришина, В. Харламенко й інших. Актуальні підходи до підготовки майбутніх учителів до організації профорієнтаційної роботи в умовах профільного навчання розглядаються в працях Т. Борисової, C. Клімова, С. Мантуленко, І. Назімова, С. Павлютенкова, Н. Пономарьової, С. Чистякової, Х. Харламенко, І. Чорної, М. Чумака й інших.

Досліджуючи категоріальну сутність профорієнтаційної компетентності майбутнього вчителя, учені наразі не дійшли єдиного висновку. Водночас, досліджуючи психолого-педагогічні, соціальні аспекти цієї проблеми, вони вказують на необхідність їі розгляду через призму здатності педагога до профорієнтаційної роботи на основі сформованої системи знань i вмінь. В. Зінченко профорієнтаційну компетентність розглядає як «комплекс особистісних можливостей педагога, які дають йому змогу ефективно й доцільно реалізовувати цілі та завдання профорієнтаційної роботи» ${ }^{1}$ Х. Процко під профорієнтаційною компетентністю розуміє «інтегративне особистісне утворення, яке обумовлює здатність майбутніх учителів технологій виконувати професійні функції в процесі здійснення профорієнтаційної роботи в загальноосвітній школі, ураховуючи потреби ринку праці та створюючи умови для професійного самовизначення особистості

Зінченко В.П., Харламенко В.Б. Формування профорієнтаційної компетентності педагога: теорія і практика : монографія. Глухів : РВВ ГНПУ імені О. Довженка, 2010. 198 с. 
учнів» ${ }^{2}$. В. Харламенко визначає профорієнтаційну компетентність як «інтегративну систему, яка містить здатність майбутніх учителів здійснювати професійні функції в процесі профорієнтаційної роботи, ураховуючи різні освітні потреби учнів, забезпечуючи обгрунтоване спрямування професійного самовизначення та створювати умови для його здійснення» ${ }^{3}$. Т. Борисова трактує категорію «профорієнтаційна компетентність» як складник професійної компетентності вчителя, яка $\epsilon$ «системним особистісним утворенням, що інтегрує профорієнтаційні знання, уміння, практичний досвід, індивідуально-ділові якості й забезпечує ефективність виконання педагогом профорієнтаційного складника професійної діяльності» ${ }^{4}$.

На нашу думку, профорієнтаційна компетентність - це цілісне утворення, що являє собою системну властивість особистості, яка включає професійно-ціннісну мотивацію, профорієнтаційні знання, уміння, практичний досвід, особистісно-професійні якості, що характеризують iii готовність i здатність до виконання профорієнтаційних функцій у майбутній професійній діяльності.

Окреслити зміст профорієнтаційної компетентності можна лише за допомогою визначення іiі структурних компонентів. Оскільки вищезазначена компетентність $є$ одним зі складників характеристики професійної компетентності вчителя, яка розглядається 3 позиції сформованих професійно-фахових якостей, здібностей, можливостей, мотивації та готовності особистості, вона обов'язково включає мотиваційний, змістовий i процесуальний компоненти. 3 погляду методології іiі формування В. Зінченко та В. Харламенко виділяють мотиваційний, когнітивний, операційний і рефлексивний компоненти 5 . Т. Борисова в структурі профорієнтаційної компетентності майбутніх учителів технології виділяє такі компоненти: «мотиваційний здатність бачити й розуміти свою педагогічну діяльність, когнітивний система знань, необхідних для здійснення діяльності профорієнтації, операційно-діяльнісний - система умінь, що дозволяють реалізувати наявні знання в типових i нестандартних ситуаціях діяльності

${ }^{2}$ Процко Х.В. Підготовка майбутніх учителів технологій до профорієнтаційної роботи у загальноосвітній школі : дис. ... канд. пед. наук : 13.00.02. Чернігів, 2009. $233 \mathrm{c}$.

3 Харламенко В.Б. Діагностика сформованості профорієнтаційної компетентності майбутнього вчителя трудового навчання. URL: http://visn_ped.gnpu.edu.ua/ Visnik\%2014.pdf.

4 Закатнов Д. Профорієнтаційні засади кар'єрного розвитку учнівської молоді. URL: file:///C:/Users/Admin/Downloads/Nvipto_2015_9_15.pdf.

Зінченко В.П., Харламенко В.Б. Формування профорієнтаційної компетентності педагога: теорія і практика : монографія. Глухів : РВВ ГНПУ імені О. Довженка, 2010. 198 с. 
профорієнтації, емоційно-вольовий - особово-професійні якості (самоконтроль, уміння управляти діями, з яких складається виконання обов'язків і так далі), що сприяють ефективній організації діяльності профорієнтації, ціннісний - здібність до самоаналізу з подальшою мотивацією саморозвитку, самовдосконалення» ${ }^{6}$. Х. Процко вважає, що компонентна структура профорієнтаційної компетентності майбутнього вчителя технологій включає «ключові змістовні компетентності, які визначаються як здатність усвідомлювати зміст професійної діяльності в процесі здійснення професійної орієнтації учнів і складаються 3 мотиваційної, когнітивної, рефлексивної компетентностей та операційно-діяльнісної компетентності - здатність виконувати визначені професійні задачі в навчально-виховному процесі, складовими якого виступають діагностична, прогностична, конструктивна, організаційна, комунікативна, технологічна, коригуюча та дослідницька компетентності» ${ }^{7}$. На нашу думку, у структурі профорієнтаційної компетентності майбутніх учителів географії доцільно, крім мотиваційного, когнітивного й рефлексивного компонентів, виділити ще операційно-діяльнісний та емоційновольовий, адже, як видно 3 міркувань науковців, кожний складник вищезазначеної компетентності зводиться до певних дій особистості, а зміст діяльнісної змістової лінії, що подається за лінійним принципом, обов'язково включає афективні - настанову, емоції, стимул, цінності, ставлення; вольові - поведінкові зусилля, мобілізація енергії, настирливість; операційні - уміння братися й вирішувати справу, власне реалізація дії.

Мотиваційно-иіннісний компонент $є$ системоутворювальним у поданій структурі, оскільки від його сформованості залежить успіх формування інших ii компонентів. В основі компонента лежить педагогічна спрямованість, що проявляється в ставленні до педагогічної діяльності. Складниками цього аспекту є потреби, що обумовлюють професійно значущу мотивацію, інтерес, рівень домагань. Якщо ці складники мають позитивний характер, то й мотивація студента щодо набуття компетентності буде насичена професійними аспектами - розумінням специфіки своєї професії та іiі спрямованості, своїх професійних функцій, орієнтацією на процес

\footnotetext{
6 Закатнов Д. Профорієнтаційні засади кар'єрного розвитку учнівської молоді. URL: file:///C:/Users/Admin/Downloads/Nvipto_2015_9_15.pdf.

${ }^{7}$ Процко Х.В. Підготовка майбутніх учителів технологій до профорієнтаційної роботи у загальноосвітній школі : дис. ... канд. пед. наук : 13.00.02. Чернігів, 2009. $233 \mathrm{c}$.
} 
професійної діяльності та ii результат, досягнення цілей ${ }^{8}$. Отже, мотиваційно-ціннісний компонент профорієнтаційної компетентності майбутнього вчителя географії включає в себе мотиви й ціннісні орієнтації, що пов'язані з усвідомленим прагненням і спрямованістю на організацію профорієнтаційної роботи та якісний результат від професійної діяльності, інтерес до предмета своєї діяльності, ціннісне засвоєння профорієнтаційних знань і формування вмінь і навичок із розв'язання завдань профорієнтації, самовдосконалення в профорієнтаційній діяльності.

Когнітивний компонент відображає рівень теоретичної підготовки майбутніх учителів, необхідної для здійснення профорієнтаційної діяльності, опанування процесуальною сутністю профорієнтаційної роботи педагога. Він включає в себе систему знань 3 теорії профорієнтації, професійної педагогіки, психології професійного самовизначення, закономірностей соціалізації та вікового розвитку особистості, профорієнтаційного процесу, форм, методів, засобів профорієнтаційної роботи в умовах профілізації навчання, освітні технології вивчення й розвитку інтересів, схильностей, методику їх застосування ${ }^{9}$. Емпіричними показниками сформованості когнітивного компонента $\epsilon$ знання змісту й етапів профорієнтаційної роботи, аспектів профорієнтації, структури системи профорієнтаційної роботи в закладах загальної середньої освіти, особливостей профорієнтаційної діяльності вчителя, методів профдіагностики ${ }^{10}$. Отже, теоретичний складник когнітивного компонента допомагає майбутньому педагогові глибше зрозуміти особливості педагогічно-профорієнтаційної роботи вчителя, усвідомити зв'язки й відносини педагогічної взаємодії в цьому контексті, а емпіричний - опанувати алгоритм проведення профорієнтаційної роботи.

Операиійно-діяльнісний компонент відображає готовність до профорієнтаційної діяльності, створює базу для самореалізації в ній і включає такий комплекс умінь для проведення профорієнтаційної роботи зі школярами:

${ }^{8}$ Мантуленко С.В. Зміст, структура та рівні готовності майбутнього вчителя до профільного навчання. Сучасні інформаційні технології та інновачійні методики навчання у підготовці фахівців: методологія, теорія, досвід, проблеми. 2013. Вип. 35. С. 350-355.

9 Чумак М.Є. Підготовка майбутніх учителів фізики до профорієнтаційної роботи з учнями загальноосвітньої школи в умовах профілізації навчання : автореф. дис. ... канд. пед. наук : 13.00.04. Переяслав-Хмельницький, 2013. 23 с.

10 Сагадіна О. Формування готовності вчителів до консультативної профорієнтаційної роботи 3 учнями старшої школи в системі підвищення кваліфікації педагогічних працівників. URL: file://C:/Users/Admin/Downloads/ Npd_2017_2_35.pdf. 
- комунікативні: установлювати педагогічно ефективні взаємозв'язки з учнями та їхніми батьками, створювати позитивний психоемоційний клімат у колективі під час проведення профорієнтації;

- конструктивно-організаторські: створювати організаційнопедагогічні умови для проведення профорієнтаційної роботи під час навчальних занять, позакласної та позаурочної роботи; проектувати індивідуальну освітню траєкторію професійного розвитку учнів 3 урахуванням їхнього творчого потенціалу та індивідуальнопсихологічних особливостей; сприяти формуванню системи професійних знань, умінь і навичок;

- аналітично-діагностичні: визначати основні профорієнтаційні завдання та способи їх оптимального вирішення, методично грамотно визначати аспекти реалізації профорієнтаційної змістової лінії в умовах відповідного предмета (географії), осягати глибинний зміст кожного профорієнтаційного явища у взаємозв'язку 3 усіма компонентами профорієнтаційного процесу, діагностувати результативність профорієнтаційної роботи, виділяти головні іiі завдання й визначати доцільні способи їх вирішення, окреслювати оптимальні форми та методи корекції професійного самовизначення учнів, сприяти свідомому й обгрунтованому професійному самовизначенню та професійній самоідентифікації серед учнівської молоді ${ }^{11}$;

- прогностичні: прогнозувати результати профорієнтаційного процесу, передбачати способи досягнення профорієнтаційних цілей через можливі відхилення, визначати етапи, розподіл часу на різні напрями профорієнтаційної роботи ${ }^{12}$.

Отже, операційно-діяльнісний компонент передбачає наявність профорієнтаційних умінь $\mathrm{i}$ навичок 3 урахуванням специфіки профорієнтаційної роботи та сприяє усвідомленню конкретних педагогічних функцій з керівництва цим процесом.

Надзвичайно важливою для професійної діяльності вчителя $\epsilon$ здатність аналізувати афективну сферу суб'єктів педагогічного процесу, проникати в психологію школяра та власної саморегуляції, оскільки він $є$ носієм не лише глибоких знань, а й високих моральних якостей, бажаної поведінки та вдалих рішень. На нашу думку, виділення емоційно-вольового компонента в структурі профорієнтаційної компетентності майбутніх учителів географії $\epsilon$

11 Зінченко В.П., Харламенко В.Б. Формування профорієнтаційної компетентності педагога: теорія і практика : монографія. Глухів : РВВ ГНПУ імені О. Довженка, 2010. 198 с.

12 Чумак М.Є. Підготовка майбутніх учителів фізики до профорієнтаційної роботи з учнями загальноосвітньої школи в умовах профілізації навчання : автореф. дис. ... канд. пед. наук : 13.00.04. Переяслав-Хмельницький, 2013. 23 с. 
об’єктивно обгрунтованим. Він сприяє формуванню емоційної стійкості й саморегуляції педагога та вмінь будувати власну програму професійної діяльності, що проявляється через такі важливі професійні якості для ефективної профорієнтаційної діяльності, як емпатія, самоконтроль, уміння керувати емоціями, діями в різних педагогічних ситуаціях.

Оиінно-рефлексивний компонент відображає здатність до рефлексії та саморефлексії, тобто змогу оцінити успіхи й виявити недоліки своєї діяльності та передбачити шляхи ії оптимізації, орієнтуючись на сильні сторони особистості в різних видах профорієнтаційної роботи під час навчання. Оцінно-рефлексивний компонент $є$ інтегрованою професійно-особистісною характеристикою педагога, що реалізується в ефективному здійсненні рефлексивних процесів, які зумовлюють успішне оволодіння профорієнтаційною діяльністю. Здатність до іiі самоаналізу потребує від учителя формування системи певних рефлексивних умінь - рефлексивно-креативних, діагностично-оцінних, контрольно-оцінювальних, рефлексивно-творчих.

Діагностично-оцінювальні - це здатність аналізувати зміст, умови, форми здійснення профорієнтаційного процесу, правильність постановки профорієнтаційних цілей і відповідність організаційних форм професійної орієнтації для їх успішної реалізації, обгрунтувати причинно-наслідкові зв'язки.

Контрольно-оцінювальні вміння включають уміння свідомо контролювати результати своєї профорієнтаційної діяльності, відповідність змісту діяльності учнів завданням профорієнтаційної роботи, оцінювати ефективність i результативність власних профорієнтаційних умінь під час профорієнтаційної роботи з учнями ${ }^{13}$.

Рефлексивно-творчі вміння - це здатність обирати альтернативні та нестандартні способи розв'язання профорієнтаційних завдань.

Специфічність оцінно-рефлексивного компонента $\epsilon$, 3 одного боку, самостійним особистісним конструктом, а 3 іншого - «наскрізною» якістю, що інтегрує такі рефлексивно насичені конструкти особистості майбутнього фахівця, як мотивація, особистісно-професійні цінності, професійна суб'єктність, які збільшують його вагомість у загальній структурі профорієнтаційної компетентності ${ }^{14} .3$ іншого боку, можна стверджувати, що структура цього феномена визначена через домінуючі профорієнтаційні компетенції.

13 Чумак М.С. Підготовка майбутніх учителів фізики до профорієнтаційної роботи з учнями загальноосвітньої школи в умовах профілізації навчання : автореф. дис. ... канд. пед. наук : 13.00.04. Переяслав-Хмельницький, 2013. 23 с.

${ }^{14}$ Професіографічний підхід у системі вищої освіти : монографія / колектив авторів ; за ред. О.А. Дубасенюк. Житомир : Вид-во О.О. Свенок, 2019. 328 с. 
Таблиця 1

Елементний склад профоріснтаційної компетентності

\begin{tabular}{|c|c|}
\hline $\begin{array}{c}\text { Складники } \\
\text { компетентності } \\
\text { (компетенції) }\end{array}$ & $\begin{array}{c}\text { Характеристика й значення } \\
\text { для професійної діяльності }\end{array}$ \\
\hline $\begin{array}{l}\text { Соціально- } \\
\text { особистісні }\end{array}$ & $\begin{array}{l}\text { 3датність застосовувати індивідуальні якості, пов'язані з } \\
\text { умінням установлювати емоційний і діловий контакт у } \\
\text { педагогічній взаємодії, працювати в групі, проявляти } \\
\text { соціальну та етичну толерантність у процесі } \\
\text { профорієнтаційної діяльності; } \\
\text { здатність бачити й розуміти свою педагогічну } \\
\text { (профорієнтаційну) діялність, свідоме бажання } \\
\text { займатися нею, усвідомлювати свою роль і призначення }\end{array}$ \\
\hline Когнітивна & $\begin{array}{l}\text { 3датність до використання теоретичних основ } \\
\text { професійної діяльності, сформованих у результаті } \\
\text { засвоєння спеціально-фахових, психолого-педагогічних } \\
\text { знань, умінь і навичок для ефективної реалізації } \\
\text { основних аспектів профорієнтаційної роботи } \\
\end{array}$ \\
\hline Дослідницька & $\begin{array}{lcc}\text { 3датність } & \text { вивчати, аналізувати педагогічні } & \text { явища, } \\
\text { проводити } & \text { експериментально-дослідну } & \text { роботу, } \\
\text { корегувати іiї програму, застосувати дослідницькі методи } \\
\text { для розв'язання практичних питань профорієнтації }{ }^{15}\end{array}$ \\
\hline Аналітична & $\begin{array}{l}\text { Уміння здійснювати психолого-педагогічний аналіз } \\
\text { освітнього та виховного процесу в контексті професійної } \\
\text { орієнтації, здійснювати самоконтроль, коректування } \\
\text { своєї професійної діяльності }\end{array}$ \\
\hline Конструктивна & $\begin{array}{l}\text { Здатність конструювати педагогічну діяльність у процесі } \\
\text { здійснення професійної орієнтації відповідно до } \\
\text { професійних інтересів, нахилів, здібностей і потреб учнів } \\
\text { (визначати конкретні навчально-виховні, профорієнта- } \\
\text { ційні завдання, планувати й аналізувати навчально- } \\
\text { виховні заходи тощо, спрямовані на розв’язання } \\
\text { профорієнтаційних завдань) }\end{array}$ \\
\hline $\begin{array}{l}\text { Проектувально- } \\
\text { управлінська }\end{array}$ & 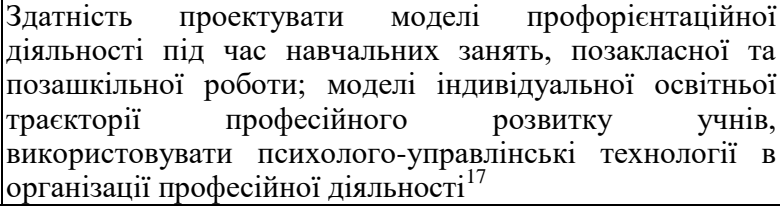 \\
\hline
\end{tabular}

15 Процко Х.В. Підготовка майбутніх учителів технологій до профорієнтаційної роботи у загальноосвітній школі : дис. ... канд. пед. наук : 13.00.02. Чернігів, 2009. 233 с.

16 Чумак М.Є. Підготовка майбутніх учителів фізики до профорієнтаційної роботи з учнями загальноосвітньої школи в умовах профілізації навчання : автореф. дис. ... канд. пед. наук : 13.00.04. Переяслав-Хмельницький, 2013. 23 с.

${ }^{17}$ Процко Х.В. Підготовка майбутніх учителів технологій до профорієнтаційної роботи у загальноосвітній школі : дис. ... канд. пед. наук : 13.00.02. Чернігів, 2009. $233 \mathrm{c}$. 
Закінчення таблиці 1

\begin{tabular}{|c|l|}
\hline $\begin{array}{c}\text { Складники } \\
\text { компетентності } \\
\text { (компетенції) }\end{array}$ & \multicolumn{1}{|c|}{ Характеристика й значення } \\
для професійної діяльності
\end{tabular}

Варто зауважити, що у зв'язку 3 досить широким спектром застосування профорієнтаційної компетентності окреслені базові складники іiі структури досить складно чітко розділити, оскільки під час професійної діяльності вони існують у єдності та взаємозалежності.

18 Синявський В.В. Професіограми і психограми професій педагогічного спрямування. Кіровоград : Імекс-ЛТД, 2014. 84 с. 


\section{2. Технологія формування профоріснтаційної компетентності в майбутніх учителів географії}

Профорієнтаційна компетентність майбутніх учителів географії має доволі складну структуру. У зв'язку з цим постає потреба в розробленні технології формування означеного феномена, практична спрямованість якої полягає у визначенні мети, завдань, шляхів і засобів їх послідовної реалізації для швидкого й ефективного досягнення конкретного педагогічного результату. Технологія формування профорієнтаційної компетентності певною мірою $є$ теоретичним конструктом процесу підготовки майбутніх учителів географії до педагогічно-профорієнтаційної діяльності, який складається з взаємопов'язаних структурних компонентів, спрямованих на формування вмінь і навичок студентів (рис. 1). На нашу думку, такими компонентами $є$ цілемотиваційний (включає мету й завдання процесу становлення профорієнтаційної компетентності та спрямований на формування ціннісного ставлення до профорієнтаційної діяльності), змістовий (спрямований на формування фундаментальних профорієнтаційних знань і теоретичних профорієнтаційних умінь у процесі фахової підготовки), операційно-діяльнісний (включає технологію формування профорієнтаційної компетентності: психолого-педагогічні умови навчання, форми, методи, засоби, організацію, контроль якості навчання, спрямований на формування практичних профорієнтаційних умінь).

Зміст фахової підготовки майбутніх учителів географії до профорієнтаційної діяльності включає такі складники: навчальні дисципліни психолого-педагогічної та науково-предметної підготовки, навчальні й виробничі практики. До блоку дисциплін психологопедагогічної підготовки, згідно з навчальним планом спеціальності 014.07 «Середня освіта (Географія)» НПУ імені М.П. Драгоманова, входять предмети психолого-педагогічного циклу («Психологія», «Педагогіка»), які дають можливість конкретизувати наявний досвід студентів, збагатити його науковими знаннями 3 педагогіки й психології, сформувати уявлення про профорієнтаційну діяльність учителя, первинні профорієнтаційні вміння під час вирішення практичних завдань i предмети методичного циклу («Методика навчання географії», «Сучасні педагогічні технології на уроках географії»), що сприяють поглибленню теоретичних знань 3 основ профорієнтації, формуванню й систематизації умінь 3 організації профорієнтаційної роботи, оволодінню методиками ії проведення ${ }^{19}$.

${ }^{19}$ Пологовська Ю.Ю. Зміст, форми та методи формування профорієнтаційної компетентності у майбутніх вчителів географії в процесі фахової підготовки. Педагогіка формування творчої особистості у вищій $i$ загальноосвітній школах : збірник наукових праць КПУ. 2019. Вип. 67. Т. 2 С. 117-124. 


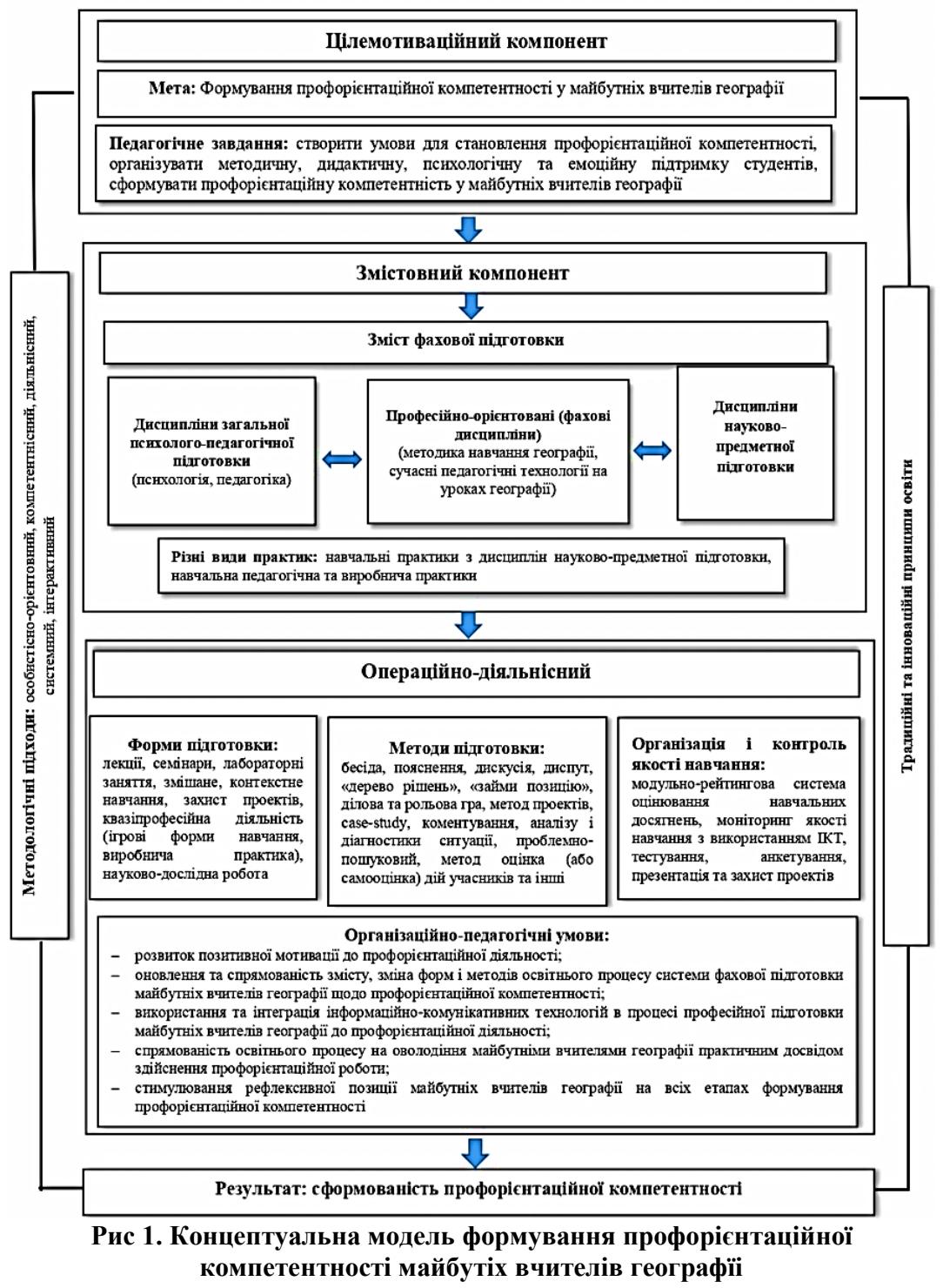

Практична підготовка студентів $є$ обов'язковим компонентом освітньо-професійної програми для здобуття освітнього ступеня й має на меті набуття ними відповідних професійних компетентностей. Ïї організаційна система, згідно 3 навчальним планом спеціальності 
014.07 «Середня освіта (Географія)» НПУ імені М.П. Драгоманова освітнього ступеня «бакалавр», включає навчальні практики 3 дисциплін науково-предметної підготовки (1-3 курси), навчальну педагогічну (3 курс) і виробничу (4 курс) практику, а освітнього ступеня «магістр» - виробничу педагогічну та науково-педагогічну $(1$ курс), переддипломну (2 курс) практику. Кожен вид практики має чітко окреслену мету і спрямування на вирішення конкретних завдань.

Зміст навчальної педагогічної практики на 3 курсі спрямований на закріплення й поглиблення теоретичних знань, отриманих студентами в процесі вивчення педагогічних і психологічних дисциплін, формування професійних компетенцій у майбутніх учителів географії. Вона включає здійснення психолого-педагогічного спостереження за педагогічним процесом, діяльністю вчителів під час навчальних занять і позакласних заходів, апробацію сформованих професійних знань і вмінь на практиці, знайомство 3 особливостями організації профорієнтаційної роботи в школі. Як результат передбачається розвиток стійкого інтересу до професії вчителя, потреби в педагогічній самоосвіті, вибір власного стилю педагогічної, профорієнтаційної діяльності, умінь складати психолого-педагогічну характеристику учняя ${ }^{20}$.

Виробнича практика розширює, поглиблює та систематизує фахові знання, уміння й навички, сприяє розвитку стійкого інтересу до майбутньої педагогічної діяльності, формуванню навичок до професійної рефлексії. Під час проходження виробничої практики в майбутніх учителів географії відбувається систематизація, конкретизація, диференціація, корекція й поглиблення набутих профорієнтаційних знань $\mathrm{i}$ вмінь. В умовах реального освітнього процесу студенти мають нагоду апробувати власні профорієнтаційні компетентності, сформувати індивідуальний стиль профорієнтаційної діяльності ${ }^{21}$.

Переддипломна практика проводиться 3 метою систематизації, поглиблення та закріплення професійних знань у виробничих умовах, формування вмінь і навичок, необхідних для виконання функцій учителя. Критеріями сформованості феномена дослідження за результатами проходження такої практики $\epsilon$ стійке позитивне ставлення до профорієнтаційної роботи, уміння на основі ціннісних пріоритетів професійного самовизначення учнів визначати специфіку

20 Сагадіна О. Формування готовності вчителів до консультативної профорієнтаційної роботи 3 учнями старшої школи в системі підвищення кваліфікації педагогічних працівників. URL: file://C:/Users/Admin/Downloads/ $\mathrm{Npd}$-2017_2_35.pdf.

$\overline{21}$ Зінченко В.П., Харламенко В.Б. Формування профорієнтаційної компетентності педагога: теорія і практика : монографія. Глухів : РВВ ГНПУ імені О. Довженка, 2010. 198 с. 
профорієнтаційної роботи й розробляти моделі профорієнтаційної діяльності, володіння методиками профорієнтаційної роботи, особиста профорієнтаційна позиція, здатність до рефлексії та саморефлексії ${ }^{22}$.

Варто зауважити, що під час проходження студентами-педагогами виробничих практик формуванню в них профорієнтаційних умінь i навичок надається другорядне значення. Профорієнтація розглядається як додаткова виховна робота 3 учнями в позаурочний час, і студентипрактиканти фактично не долучаються до активних форм іiї проведення навіть під керівництвом учителя. Основними напрямами їхньої профорієнтаційної діяльності $\epsilon$ поширення рекламних матеріалів про навчальний заклад, де навчаються, та проведення профорієнтаційних анкетувань за потреби (на вимогу керівництва школи або для підготовки експериментального складника бакалаврських, магістерських робіт).

Результативним компонентом у системі формування профорієнтаційної компетентності в майбутніх учителів географії $є$ написання курсової, бакалаврської чи магістерської роботи 3 питань дослідження цього феномена. Кожен із цих видів роботи синтезує елементи власного творчого пошуку, забезпечує опрацювання досвіду 3 проблеми досліджування та продукує самостійні спостереження й висновки студента. Студент на основі проведення власного дослідження узагальнює та систематизує знання, отримані протягом усього періоду навчання у виші, працює над розробленням власної методики проведення профорієнтаційної роботи в старшій школі загалом чи окремих їх складників, позиціонуючи себе як суб'єкт навчання, може запропонувати власні методичні рекомендації щодо формування профорієнтаційної компетенції в студентів під час навчання в закладах вищої освіти.

У процесі становлення профорієнтаційної компетентності під час фахової підготовки доцільно виділити три етапи. Перший етап пов'язаний із засвоєнням змісту професійної підготовки, розвитком цілісного уявлення про профорієнтаційну діяльність, спрямований на систематизацією та інтеграцією теоретичних знань про основні об'єкти профорієнтаційної роботи вчителя й формування первинних прикладних умінь вирішувати профорієнтаційні завдання, розвиток професійної мотивації до обраного фаху та профорієнтаційній діяльності $^{23}$. На цьому етапі передбачається формування мотиваційно-

${ }^{22}$ Пологовська Ю.Ю. Зміст, форми та методи формування профорієнтаційної компетентності у майбутніх вчителів географії в процесі фахової підготовки. Педагогіка формування творчої особистості у вищій $i$ загальноосвітній школах : збірник наукових праць КПУ. 2019. Вип. 67. Т. 2. С. 117-124.

23 Чумак М.С. Підготовка майбутніх учителів фізики до профорієнтаційної роботи з учнями загальноосвітньої школи в умовах профілізації навчання : автореф. дис. ... канд. пед. наук : 13.00.04. Переяслав-Хмельницький, 2013. 23 с. 
ціннісного й когнітивного компонентів профорієнтаційної компетентності. Другий етап передбачає відпрацювання умінь i навичок у ситуаціях ігрової взаємодії власне на практиці, набуття первинного досвіду розв'язування завдань профорієнтаційного спрямування. Відбувається формування операційно-діяльнісного, рефлексивного та емоційно-вольового компонентів. Третій етап спрямовано на вдосконалення вмінь $\mathrm{i}$ навичок організації профорієнтаційної роботи в закладах загальної середньої освіти, становлення професійної самосвідомості, структурними компонентами якої в контексті дослідження $є$ адекватна професійна самооцінка студентами результатів їхньої профорієнтаційної діяльності, самоаналіз досягнень i прорахунків, аналіз їх причин 3 метою подальшого корегування. Зазначені етапи формування профорієнтаційної компетентності в майбутніх учителів географії не $є$ ізольованими один від одного в часі, адже $є$ складниками цілісного психологопедагогічного процесу становлення готовності студентів до профорієнтаційної діяльності, а вирізняються лише специфікою в меті, змісті, формах, засобах, методах і результатах освітнього процесу ${ }^{24}$.

Важливими елементами моделі, які визначають зміст, організаційні форми та методи навчальної роботи, є підходи й принципи навчання. Методологічною основою формування профорієнтаційної компетентності в майбутніх учителів географії є гуманістична модель освіти, що спрямована на створення умов для розвитку й саморозвитку особистості, самореалізації індивідуальних здібностей і формування професійної компетентності. Провідними підходами, які дають змогу реалізувати гуманістичні ідеї в системі формування готовності майбутніх учителів до профорієнтаційної роботи, є такі:

- особистісно-орієнтовний - передбачає спрямованість педагогічного процесу на потреби та можливості особистості, а основоположними його складниками $\epsilon$ самоактуалізація, індивідуальність, ініціативність, самостійність у прийнятті рішень, творчість, креативність, новаторство;

- компетентнісний - передбачає зміщення акцентів із засвоєння знань, умінь і навичок на формування здатності практично діяти, приймати ефективні рішення, активної життєвої позиції в усіх сферах суспільного життя, а також навичок безперервної самоосвіти та рефлексії;

24 Ляшенко М.Ю. Технологія формування фахової компетентності вчителів трудового навчання i технологій 3 основ підприємництва. URL: http://enpuir.npu.edu.ua/bitstream/123456789/13346/1/Liashenko\%20M\%2C\%202017\%2 C\%20Poland.pdf. 
- діяльнісний - передбачає організацію підготовки фахівця 3 опорою на модель майбутньої діяльності й активізує включення студентів у різноманітні професійно-педагогічні відносини;

- системний - передбачає єдність теоретичної та практичної підготовки;

- інтерактивний - передбачає впровадження інтерактивних методів навчання, які сприяють інтенсифікації та оптимізації процесу оптимізації фахової підготовки, стимулюванню й мотивації пізнавальної активності майбутнього педагога 25 .

Сучасна теорія та практика формування основ професійної компетентності майбутніх фахівців базується на системі методологічних, загальнопедагогічних, андрогонічних, дидактичних, психологічних принципів залежно від мети й завдань. Ураховуючи мету й завдання дослідження, виділяємо такі групи дидактичних принципів, які забезпечать ефективність його виконання: традиційні принципи науковості, системності й послідовності, наступності, зв'язок теорії 3 практикою, наочності, індивідуалізації навчання; інформаційну освіту й інноваційні принципи - інтенсифікації навчання, інтерактивного навчання, інноваційної наочності, креативного розвитку ${ }^{26}$.

Розкриваючи основні аспекти процесу формування профорієнтаційної компетентності майбутніх учителів географії, необхідно визначити перелік організаційно-педагогічних умов, які б давали змогу ефективно вирішувати поставлену мету з урахуванням специфіки та особливостей майбутньої професійної діяльності. На нашу думку, до таких організаційно-педагогічних умов належать:

- розвиток позитивної мотивації до профорієнтаційної діяльності як способу оволодіння майбутньою професією та професійного становлення;

- оновлення та спрямованість змісту, зміна форм і методів освітнього процесу системи фахової підготовки майбутніх учителів географії щодо профорієнтаційної компетентності;

- використання й інтеграція інформаційно-комунікативних технологій у процесі професійної підготовки майбутніх учителів географії до профорієнтаційної діяльності;

25 Гращенкова Ж. Формування професійної компетентності майбутнього тренера 3 плавання у процесі вивчення фахових дисциплін. URL: https://ps.journal.kspu.edu/index.php/ps/article/view/3501/3095.

26 Ляшенко М.Ю. Технологія формування фахової компетентності вчителів трудового навчання i технологій 3 основ підприємництва. URL: http://enpuir.npu.edu.ua/bitstream/123456789/13346/1/Liashenko\%20M\%2C\%202017\%2 C\%20Poland.pdf. 
- спрямованість освітнього процесу на оволодіння майбутніми вчителями географії практичним досвідом здійснення профорієнтаційної роботи;

- стимулювання рефлексивної позиції майбутніх учителів географії на всіх етапах формування профорієнтаційної компетентності ${ }^{27}$.

Ефективність формування профорієнтаційної компетентності в майбутніх учителів географії також залежить від форм, методів i засобів навчання, які використовують викладачі. Під час становлення профорієнтаційної компетентності використовуються як традиційні, так і нетрадиційні форми навчання та роботи. До традиційних форм навчання зараховують лекції, практичні, лабораторні, семінарські заняття, консультації, які передбачають передачу знань, але не завжди формують професійні вміння й навички в майбутніх фахівців. Дієвим засобом є впровадження в освітній процес закладів вищої освіти інноваційних технологій навчання, які забезпечують наближення професійної підготовки педагогічних кадрів до реальної практичної діяльності й зорієнтовані на особистість студента, його активну участь у саморозвитку, отримання якісних знань, формування професійних умінь тощо. Серед новітніх педагогічних технологій, які, на нашу думку, максимально сприятимуть формуванню профорієнтаційної компетентності майбутніх учителів географії, варто виділити ігрові, проектні технології, технології контекстного та комп'ютерного навчання, що дають змогу оптимально враховувати професіографічні вимоги обраної студентами спеціальності, засвоїти навчальний матеріал, закріпити, продіагностувати і скоригувати знання, уміння та навички. Упровадження в освітній процес інноваційних педагогічних технологій передбачає систематичне залучення студентів до індивідуальної, групової самостійної та науково-дослідної діяльності ${ }^{28}$.

Досить ефективними, нашу думку, засобами активізації мотиваційного компонента профорієнтаційної компетентності майбутніх учителів географії в системі фахової підготовки $є$ їх залучення як волонтерів до організації та проведення профорієнтаційної роботи кафедри, факультету й проведення спільно 3 учителями закладів загальної середньої освіти та приватних навчальних

27 Пологовська Ю.Ю. Організаційно-педагогічні умови формування профорієнтаційної компетентності у майбутніх вчителів географії. Science and Education a New Dimension. Pedagogy and Psychology. 2019. № 86. Issue: 209. P. 39-45.

28 Пологовська Ю.Ю. Зміст, форми та методи формування профорієнтаційної компетентності у майбутніх вчителів географії в процесі фахової підготовки. Педагогіка формування творчої особистості у вищій $i$ загальноосвітній школах : збірник наукових праць КПУ. 2019. Вип. 67. Т. 2. С. 117-124. 
закладів (бізнес-школи), тренінгів, під час яких педагоги зможуть поділитися своїм досвідом, а студенти, потрапивши в рефлексивну позицію, напрацювати ресурс для вирішення професійних ситуацій, сформувати свій ідеальний (внутрішній) план професійної діяльності.

\section{ВИСНОВКИ}

У результаті проведеного дослідження встановлено, що формування профорієнтаційної компетентності майбутніх педагогів грунтується на потребах сьогодення, $\epsilon$ обов'язковим компонентом професійної підготовки, а досліджуваний феномен являє собою системну особисту освіту, інтегруючі профорієнтаційні знання й уміння, практичний досвід, особисто-професійні якості, що забезпечують ефективність виконання профорієнтаційних функцій у майбутній професійній діяльності.

Формування профорієнтаційної компетентності - це складний i багатоетапний процес, який залежить від цілого комплексу спеціальних організаційно-дидактичних умов, що спрямовані на поетапне моделювання та ефективне функціонування процесу становлення й розвитку належного рівня такої компетентності i, як результат, полегшує входження майбутніх педагогів до професії, забезпечує подальшу успішну їх реалізацію в ній. Технологія формування профорієнтаційної компетентності включає в себе три етапи становлення профорієнтаційної компетентності, кожен із яких $є$ завершеним циклом іiі розвитку, а реалізація цільової домінанти на кожному з них передбачає застосування оптимально поєднаних методів, засобів, форм, технологій навчання та видів діяльності студента, що в результаті сприяють формуванню цілісної, внутрішньомотивованої готовності студентів до профорієнтаційної діяльності. Методологічною основою формування профорієнтаційної компетентності в майбутніх учителів географії $є$ гуманістична модель освіти, яка спрямована на створення умов для розвитку й саморозвитку особистості, самореалізації індивідуальних здібностей і формування професійної компетентності. Провідними підходами, які дають змогу реалізувати гуманістичні ідеї в системі формування готовності майбутніх учителів до профорієнтаційної роботи, $€$ особистісно-орієнтовний, компетентнісний, діяльнісний, системний та інтерактивний.

Практичний аспект формування профорієнтаційної компетентності спрямований на подолання протиріч між соціально-економічними вимогами суспільства до готовності учнів до вибору майбутньої професії та відносно низьким рівнем професійного самовизначення; між потребою в організації профорієнтаційної роботи в школі й недостатнім рівнем сформованості профорієнтаційної компетентності вчителя; між необхідністю підвищення рівня сформованості профорієнтаційної компетентності в майбутніх учителів географії й 
недостатньою розробленістю теоретичних, методологічних i технологічних основ вирішення цієї проблеми.

\section{АНОТАЦІЯ}

У статті розглянуто проблему формування профорієнтаційної компетентності як складника професійної компетентності майбутніх учителів географії. Наведено підходи до трактування сутності профорієнтаційної компетентності вчителя. На основі аналізу наукових досліджень визначено структуру профорієнтаційної компетентності, яка включає мотиваційно-ціннісний, когнітивний, операційнодіяльнісний, емоційно-вольовий та оцінно-рефлексивний компоненти. Представлено технологію формування профорієнтаційної компетентності в майбутніх учителів географії, яку побудовано з урахуванням специфіки виконання ними професійних завдань і розв'язання типових ситуацій профорієнтаційного спрямування. Визначено структурні компоненти моделі формування профорієнтаційної компетентності, а саме: цілемотиваційний, змістовий, операційно-діяльнісний. Проаналізовано значення кожного компонента в процесі формування належного рівня цієї компетентності. Запропоновано механізм реалізації моделі формування профорієнтаційної компетентності в майбутніх учителів географії в освітньому процесі закладів вищої освіти.

\section{ЛIТЕРАТУРА}

1. Гращенкова Ж. Формування професійної компетентності майбутнього тренера 3 плавання у процесі вивчення фахових дисциплін. URL: https://ps.journal.kspu.edu/index.php/ps/article/view/ $3501 / 3095$.

2. Закатнов Д. Профорієнтаційні засади кар'єрного розвитку учнівської молоді. url: file:///C:/Users/Admin/Downloads/Nvipto_2015_ 9_15.pdf.

3. Зінченко В.П., Харламенко В.Б. Формування профорієнтаційної компетентності педагога: теорія і практика : монографія. Глухів : РВВ ГНПУ імені О. Довженка, 2010. 198 с.

4. Ляшенко М.Ю. Технологія формування фахової компетентності вчителів трудового навчання і технологій 3 основ підприємництва. URL: http://enpuir.npu.edu.ua/bitstream/123456789/13346/1/Liashenko\% 20M\%2C\%202017\%2C\%20Poland.pdf.

5. Мантуленко С.В. Зміст, структура та рівні готовності майбутнього вчителя до профільного навчання. Сучасні інформачійні технології та інноваційні методики навчання у підготовці фахівців: методологія, теорія, досвід, проблеми. 2013. Вип. 35. С. 350-355. 
6. Пологовська Ю.Ю. Зміст, форми та методи формування профорієнтаційної компетентності у майбутніх вчителів географії в процесі фахової підготовки. Педагогіка формування творчої особистості у вищій $i$ загальноосвітній школах : збірник наукових праць КПУ. 2019. Вип. 67. Т. 2. С. 117-124.

7. Пологовська Ю.Ю. Організаційно-педагогічні умови формування профорієнтаційної компетентності у майбутніх вчителів географії. Science and Education a New Dimension. Pedagogy and Psychology. 2019. № 86. Issue: 209. P. 39-45.

8. Професіографічний підхід у системі вищої освіти : монографія / колектив авторів ; за ред. О.А. Дубасенюк. Житомир : Вид-во О.О. Свенок, 2019. $328 \mathrm{c}$.

9. Процко Х.В. Підготовка майбутніх учителів технологій до профорієнтаційної роботи у загальноосвітній школі : дис. ... канд. пед. наук : 13.00.02. Чернігів, 2009. 233 с.

10. Сагадіна О. Формування готовності вчителів до консультативної профорієнтаційної роботи з учнями старшої школи в системі підвищення кваліфікації педагогічних працівників. URL: file:///C:/Users/ Admin/Downloads/Npd_2017_2_35.pdf.

11. Синявський В.В. Професіограми і психограми професій педагогічного спрямування. Кіровоград : Імекс-ЛТД, 2014. 84 с.

12. Стеценко Н. Формування професійної компетентності майбутніх учителів шляхом підвищення їх практичної підготовки. URL: https://dspace.udpu.edu.ua/jspui/bitstream/6789/315/1/competence.pdf.

13. Харламенко В.Б. Діагностика сформованості профорієнтаційної компетентності майбутнього вчителя трудового навчання. URL: http://visn_ped.gnpu.edu.ua/ Visnik\%2014.pdf.

14. Чумак М.Є. Підготовка майбутніх учителів фізики до профорієнтаційної роботи з учнями загальноосвітньої школи в умовах профілізації навчання : автореф. дис. ... канд. пед. наук : 13.00.04. Переяслав-Хмельницький, 2013. 23 с.

\section{Information about the authors: Pologovska Yu. Yu.,} Lecturer at the Department of Geography National Pedagogical Dragomanov University 9, Pyrogova str., Kyiv, 01601, Ukraine

Shchabelska V. H., Candidate of Geographic Sciences (Ph.D.), Associate Professor, Head of the Department of Geography National Pedagogical Dragomanov University 9, Pyrogova str., Kyiv, 01601, Ukraine 